\title{
EWA KUBIAK ${ }^{1}$
}

Uniwersytet Łódzki

ORCID 0000-0002-2740-0632

\section{BARWNY SPLENDOR SAKRALNYCH WNECTRZ JEZUICKICH W CUSCO (PERU) W ŚWIETLE OSIEMNASTOWIECZNYCH INWENTARZY}

\section{The colourful splendour of the Jesuit sacred interiors in Cusco (Peru) in the light of the eighteenth-century inventories}

\begin{abstract}
The article presents eighteenth-century inventories as sources of knowledge about the details of the decoration of the Jesuit sacred interiors in Cusco. The author focuses on presenting the colours in the interiors of the church and chapels. In the first section, the author analyses the content of the inventories themselves and the denominations of colours, briefly describing the names, use and meaning of each colour. In the second part of the study, the author discusses the colours of selected elements of the decoration, such as the tabernacles, antependia and costumes of sculptures in the altars. The problem was presented in the cultural context of the region, with both baroque and Andean aesthetics considered.
\end{abstract}

Keywords: Cusco, interior decoration, colours, colonial architecture, Society of Jesus

\begin{abstract}
Abstrakt
W artykule zostały przedstawione osiemnastowieczne inwentarze jako źródła wiedzy na temat szczegółów wystroju jezuickich wnętrz sakralnych w Cusco. Autorka skupia się na zaprezentowaniu kolorystyki we wnętrzach kościoła i kaplic. W pierwszej części analizuje treść samych inwentarzy i denominacje kolorów, krótko charakteryzuje też same nazwy, użycie i znaczenie poszczególnych barw. W drugiej części opracowania została opisana kolorystyka wybranych elementów wystroju, takich jak tabernakula, antependia oraz stroje rzeźb w ołtarzach. Problem został ukazany w kontekście kulturowym regionu, pod uwagę zostały wzięte zarówno elementy estetyki barokowej, jak i andyjskiej.
\end{abstract}

\footnotetext{
1 Dr Ewa Kubiak, historyczka sztuki, adiunkt w Instytucie Historii Sztuki Uniwersytetu Łódzkiego. Od 2003 zajmuje się sztuką Ameryki Łacińskiej okresu wicekrólestwa. Od 2017 r. współpracuje z Centrum Badań Andyjskich Uniwersytetu Warszawskiego i dzięki jego wsparciu realizuje badania skoncentrowane na sztuce kuzkeńskiej. Autorka licznych publikacji z zakresu sztuki kolonialnej opublikowanych w językach polskim, hiszpańskim, angielskim i portugalskim. Visiting professor na uniwersytetach amerykańskich: Universidad de los Andes (Bogota, Kolumbia) oraz Universidad Nacional de San Antonio Abad en Cusco (Peru). E-mail: ewa.kubiak@uni.lodz.pl.
} 
Słowa kluczowe: Cusco, wystrój wnętrz, barwy, architektura kolonialna, Towarzystwo Jezusowe

\section{Rola barwy w kulturze andyjskiej}

ztuka kolonialna od pewnego czasu budzi coraz większe zainteresowanie badaczy. Zachwyca jej odmienność i bogactwo. Zajmujący się nią zwykle skupiają się na wyjątkowych formach i ikonografii będącej mieszanką znaczeń i symboli wywodzących się z Europy i lokalnych tradycji indiańskich. Opisywane są dekoracje rzeźbiarskie portali, wychwytywane motywy ikonograficzne nawiązujące do elementów miejscowej flory i fauny. Przepych, splendor i bogactwo ujmowane są w kontekście nagromadzenia form i dwuznaczności znaczeń. Jednak nie mniejsze znaczenie w kształtowaniu sztuki kolonialnej miał kolor. W spektakularny sposób widoczne jest to w mniejszych ośrodkach. Wówczas architektura zewnętrzna jest niezwykle skromna, bielone kościoły o prostej strukturze wznoszone z adobe $e^{2}$, pozbawione zewnętrznych dekoracji, nie zachęcają gościa do wizyty wewnątrz. Jednak, gdy już odwiedzający skusi się, aby wejść do świątyni, staje w obliczu nie tylko bogactwa form, ale i feerii barw. Przykładem takiego obiektu może być kościół pod wezwaniem Matki Boskiej Niepokalanie Poczętej znajdujący się w Checacupe niedaleko Cusco. Obiekt został ukończony przed 1687 r. ${ }^{3}$, z ołtarzem głównym pochodzącym z początku XVIII w. ${ }^{4}$ i barwną polichromią z różnych epok ${ }^{5}$ (il. 1).

Barwy w estetyce andyjskiej odgrywały i nadal odgrywają bardzo ważną rolę. Bogactwo kolorystyczne obecne jest w przestrzeni miast i osad przede wszystkim za sprawą tkanin, z których wykonywane są tradycyjne stroje lub przynajmniej fragmenty ubioru. Obecnie wiele elementów codziennego stroju jest zeuropeizowanych, ale kobiety, nawet noszące współczesne ubrania, bardzo często na plecach mają przytroczone chusty (mantas) wykonane z wielobarwnej tkaniny. Kalejdoskop barw widać na co dzień, ale obecność kolorów w przestrzeni miasta intensyfikuje się podczas świąt (il. 2). Stroje prezentowane na ilustracjach pochodzą z Cusco i regionu. Pierwsza fotografia została wykonana w 2020 r. na głównym placu miasta podczas procesji społeczności z Paucartambo, kiedy wierni odbierali z kuzkeńskich warsztatów konserwacji zabytków odnowiony, otaczany kultem wizerunek Señora de Mahuayani (nazywany też Señor de Tayankani). Drugie zdjęcie, ukazujące przewieszone przez plecy kobiece mantas, pochodzi z placu z podkuzkeńskiego San Jerónimo i zostało wykonane w 2018 r. w świąteczną Niedzielę Palmową. Trzecia fotografia przedstawia fragment

\footnotetext{
Cegła suszona na słońcu. Najbardziej typowy budulec prowincji andyjskich.

3 Biskup Cusco Manuel de Mollinedo y Angulo podczas wizyty duszpasterskiej w 1674 r. ocenił stan kościoła na bardzo zły, wspominał, że mury grożą zawaleniem i nakazuje wzniesienie nowej świątyni: „mandé derrivar su iglesia para edificarla de nuevo pasado invierno, por averla hallado amenasando ruina". G.M. Viñuales, R. Gutiérrez, Historia de los pueblos de indios de Cusco y Apurímac, Lima 2014, s. 530; P. Guibovich Pérez, L.E. Wuffarden, Sociedad y gobierno episcopal: las visitas del obispo Mollinedo y Angulo (Cuzco 1674-1694), Lima 2008, s. 84. Podczas kolejnej wizyty w 1687 odnajduje kościół w dobrym stanie, choć wydaje się, że niedokończony, gdyż zleca „dokończenie malowania prezbiterium [...] oraz pomalowanie baptysterium i zakrystii /que se acabe la pintura de la capilla mayor [...] que se pinte el babtisterio y sacristía”. Jest to już zapewne nowy kościół, który istnieje do czasów obecnych. P. Guibovich Pérez, L.E. Wuffarden, op. cit., s. 223.

4 Na początku XVIII w. proboszczem parafii był Bernardo de Valenzuela y Centeno. Z jego inicjatywy wzniesiono ołtarze zarówno w Checacupe, jak i pobliskiej Pitumarce; G.M. Viñuales, R. Gutiérrez, op. cit., s. 532.

5 P. Macera, La pintura mular andina. Siglos XVI-XIX, Lima 1993, s. 78-79.
} 

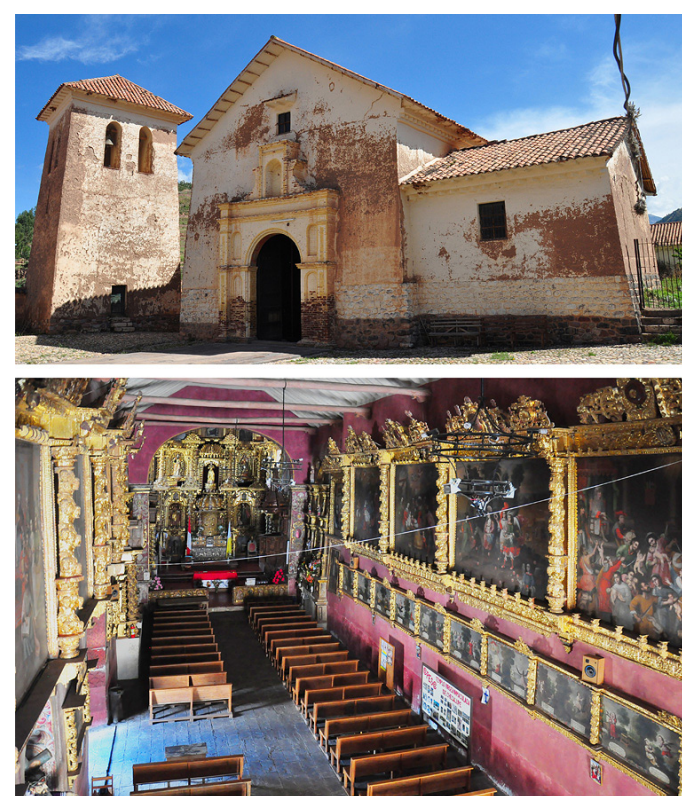

I1. 1. Kościół parafialny pod wezwaniem Matki Boskiej Niepokalanie Poczętej, Checacupe, ukończony 1686 r., wystrój kon. XVII i XVIII w. (fot. E. Kubiak, 2018) andyjskiej barwnej tkaniny, która prezentuje tradycyjne, pasowe cieniowanie kolorów ${ }^{6}$.

Dwa ostatnie zdjęcia mogą być ilustracją do studiów chilijskiej badaczki Veroniki Cerecedy ${ }^{7}$, opisującej ciekawe zdarzenie, którego doświadczyła w czasie swoich badań terenowych. Przebywając wśród Indian Isluga ${ }^{8}$, zapytała, jaki jest najpiękniejszy motyw, który można by było utkać. W tym rejonie tkaniny słyną z dekoracji składających się z małych figurek, którymi ozdabia się szarfy. Niewielkie orły, czaple, strusie czy kaczki umieszczane są w krajobrazie zaznaczanym motywami drzew i kwiatów. Jednak odpowiedź zaskoczyła badaczkę. Okazało się, że najładniejsze są k’isay, czyli wąskie pasy cieniowanych kolorów układane w sekwencjach jasnych i ciemnych barw. Tkaniny mogą mieć naturalny koloryt zależny od poszczególnych tonów barwnych niefarbowanej wełny, wówczas nazywane są qura (czyli ,surowa”) $k$ 'isa.

Za bardziej wyszukane uznawane są jednak te, które otrzymuje się w wyniku barwienia włókien, a tkaczka sama wybiera kolory, których chce użyć. Taka tkanina nazywana jest p'ana k'isay, gdzie p'ana określa kolory otrzymywane w procesie farbowania9. Jak pisze autorka: „Na pierwszy rzut oka p'ana k'isas wybuchają odblaskowym kolorem. Jednak, gdy obejrzeć je uważnie, można zauważyć, że obok tonów bardzo czystych i żywych, $k$ 'isay pozwalają sobie również na włączenie tonów nieczystych i matowych, takich jak czarny by czasem podkreślić zupełny brak światła, albo biały - aby uzyskać efekt odwrotny, czyli padania światła; a także odcieni bardzo wyblakłych, jak błękit czy bladoróżowy, niemających żadnej siły oddziaływania"lo.

Wiele elementów strojów ludności tubylczej Andów zmienia się w zależności od regionów, ale są i takie jak talagas (tkane sakwy z motywami pasów), które spotkać można w bardzo odległych regionach południowych Andów, nad brzegami jeziora Titicaca, w Arequipie czy

\footnotetext{
6 Tkanina jest własnością autorki artykułu.

7 Verónica Cereceda, antropolożka chilijska, prowadzi badania dotyczące tkanin regionu andyjskiego. Obroniła dwa doktoraty, pierwszy z etnologii, drugi zaś z semiotyki ogólnej. Studiowala w Limie i w Paryżu, obecnie jest przewodniczącą Fundación para la Investigación Antropólogica y el Etnodesarrollo "Antropólogos del Surandino". 8 Ludność tubylcza grupy Ajmara zamieszkująca płaskowyż w północnej części Chile u podnóża wulkanu o tej samej nazwie.

9 V. Cereceda, O pewnych aspektach estetyki ajmarsko-andyjskiej: od pojęcia piękna do tinku, w: Estetyka Indian Ameryki Południowej. Antologia, red. K. Zajda, tłum. N. Pluta, Kraków 2007, s. 24-25.

10 Ibidem, s. 25.
} 
w Cusco ${ }^{11}$. Podobnie uniwersalny charakter ma pasowa dekoracja określana w języku ajmara $k^{\prime}$ isay. Cieniowanie barw, przypominające kolory pryzmatu, można wiązać z tęczą, która od zamierzchłych czasów obecna jest w mitologiach andyjskich ${ }^{12}$. Liniowa gradacja kolorów jest wizualizacją światła i blasku, które są postrzegane jako najwyższe piękno' ${ }^{13}$.

Kolor w sztuce kolonialnej Wicekrólestwa Peru był przedmiotem kilku studiów. Najważniejsze są prace argentyńskiej badaczki Gabrieli Siracusano ${ }^{14}$. Książka zatytułowana El poder de los colores ${ }^{15}$ jest najpełniejszym studium, choć autorka wydała także, współpracując z grupą badaczy, kilka krótszych, szczegółowych artykułów poświęconych użyciu poszczególnych barw ${ }^{16}$. Poza tym można wymienić kilka opracowań, w których kolor jest analizowany jako jeden $z$ elementów formalnych i symbolicznych w odniesieniu do konkretnego obiektu arty-
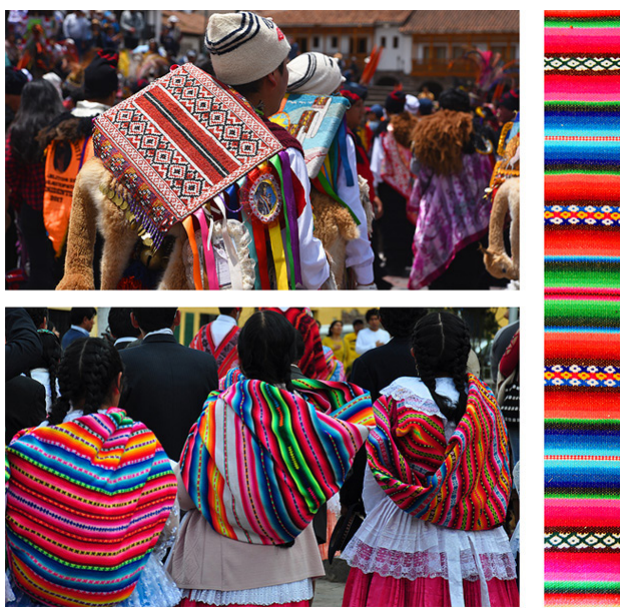

I1. 2. Procesja Bractwa Señora de Mahuayani z Paucartambo, Plaza de Armas w Cusco, 2020; Kobiety ze społeczności San Jerónimo (Cusco) podczas Niedzieli Palmowej, 2018; fragment tkaniny peruwiańskiej z dekoracją pasową, własność autorki (fot. E. Kubiak) stycznego lub grupy dzieł sztuki ${ }^{17}$. Jako tło

11 Idem, Semiología de los textiles andinos: las talegas de Isluga, „Chungara. Revista de Antropología Chilena”, 42/2010, nr 1, s. 182.

12 O pochodzeniu $k$ 'isay od tęczy wspomina także Vernica Cereceda: V. Cereceda, $O$ pewnych..., op. cit., s. 25.

13 Barwy strojów inkaskich miały także znaczenie symboliczne, były oznaką władzy; za pomocą kolorów określano też status społeczny. Konkretne bóstwa związane były ze swoimi kolorami; barwy strojów odgrywały również bardzo ważną rolę w kultach religijnych; E. Phipps, Color in the Andes: Inca Garments and 17th-Century Colonial Documents, „Dyes in History nad Archeology”, 2003, nr 19, s. 52. Więcej o tkaninach andyjskich: D.E. Blum, Textiles in Colonial Latin America, w: The Arts in Latin America, red. J.J. Rishel, S. Stratton-Pruir, Mexico City, New Haven, London, 2006, s. 146-154; T. Gisbert, S. Arze, M. Cajias, Arte Textil y Mundo Andino, La Paz (Bolivia) 2015 [1988]; E. Phipps, Cumbi to Tapestry: Collection, Innovation, and Transformation of the Colonial Andean Tapestry Tradition, w: The Colonial Andes. Tapestries and Silverwork, 1530-1830, red. E. Phipps, J. Hecht, C.E. Martín, New York-New Haven-London 2004, s. 73-99.

14 Gabriela Siracusano, argentyńska historyczka sztuki, specjalizuje się w analizie materialnego wymiaru obiektów artystycznych, w tym także barwników. Jej badania obejmują dzieła od czasów starożytnych po współczesne, jednak swoje najbardziej znane studia poświeciła obiektom artystycznym powstałym w okresie wicekrólestwa: szczególnie interesuje ją region andyjski. Absolwentka Uniwersytetu Buenos Aires (UBA), jest dziś głównym badaczem w Conicet, profesorem UBA i Universidad Nacional de Tres de Febrero (UNTREF), gdzie kieruje również Centro de Investigación en Arte, Materia y Cultura (MATERIA).

15 G. Siracusano, El poder de los colores. De lo material a lo simbólico en las practicas culturales andinas. Siglos XVI-XVIII, Buenos Aires 2005; A.M. Seldes, J.E. Burucúa, M.S. Maier, G .Abad, A. Jáuregui, G. Siracusano, Blue Pigments In South American Painting (1610-1780), „Journal of the American Institute for Conservation”, 38/1999, nr 1, s. 100-123; A.M. Seldes, J.E. Burucúa, G. Siracusano, M.S. Maier, G.E. Abad, Green, Red and Yellow Pigments In South American Painting (1610-1780), „Journal of the American Institute for Conservation”, 41/2002, nr 3, s. 225-242.

16 G. Siracusano, Colors and Cultures in the Andes, w: Colors Between Two Worlds: The Florentine Codex of Bernardino de Sahagún, red. G. Wolf, J. Connors, L, Waldman, Florence 2011, s. 367-377.

17 G. Siracusano, Coloreando el ánimo de los fieles: saberes y poderes del color en el pensamiento jesuita, siglos XVI-XVII, w: Los jesuitas y la modernidad en Iberoamérica (1549-1773), red. M. Marzal, L. Bacigalupo, t. 2, 
porównawcze warto także wskazać kilka opracowań dotyczących terenów Wicekrólestwa Nowej Hiszpanii ${ }^{18}$.

\section{Określenia kolorów w inwentarzach}

Moje dotychczasowe badania z zakresu sztuki kolonialnej Wicekrólestwa Peru dokonywały się w dwóch nurtach: manifestacji artystycznych zakonu jezuitów oraz ikonografii w malarstwie nowożytnym. Obecnie przygotowuję książkę na temat architektury okazjonalnej w Cusco, co wiąże się z rozbudowanymi analizami dokumentów archiwalnych. Moje zainteresowania badawcze z zakresu sztuki kolonialnej zostały także wzmocnione wrażliwością językową, która pewnie istniała zawsze, ale udało się ją usystematyzować w sposób naukowy podczas studiów z zakresu filologii hiszpańskiej. Wszystko to wpłynęło na wybór tematu niniejszego opracowania.

Kiedy z ziem hiszpańskojęzycznych kolonii w Ameryce wygnano członków zakonu jezuitów, powołany został organ określony jako Zarząd Dóbr (Junta de Temporalidades ${ }^{19}$ ). Był on odpowiedzialny za sporządzenie spisów dóbr należących do jezuitów, a także administrację i przekazanie własności zakonu nowym zarządcom lub jej sprzedaż. Większość sporządzonych w tym czasie inwentarzy datowana jest na lata $1767-1768^{20}$. Do niniejszego artykułu jako materiał źródłowy posłużyły cztery inwentarze obiektów sakralnych w Cusco: kościoła i kolegium pod wezwaniem Przemienia Pańskiego (Transfiguración) ${ }^{21}$, związanej ze społecznością indiańską kaplicy Matki Boskiej Loretańskiej²2 oraz dwóch kaplic kolegiów jezuickich: szkoły przeznaczonej dla młodzieży kreolskiej Świętego Bernarda oraz drugiej - dla potomków lokalnych elit indiańskich Świętego Franciszka Borgiasza ${ }^{23}$. Wszystkie

Lima 2007, s. 105-116; E. Phipps, N. Turner, K. Trentelman, Colors, Textiles, and Artistic Production in Murúa `s Historia General del Piru, w: The Getty Murúa. Essays on the Making of Martín de Murúa's Historia General del Piru, J. Paul Getty Museum Ms. Ludwig XIII 16, red. T.B. F. Cummins, B. Anderson, Los Angeles 2008, s. 125-145; E. Phipps, Textile Colors and Colorants in the Andes, w: Colors Between..., op. cit., s. 257-280.

18 C. Bargellini, The Colors of the Virgin of Guadalupe, w: Colors Between..., op. cit., s. 3-25. R. Bruquetas Galán, Local and Importes colors: The Spanish Maritme Trade and the Pigment Supply in New Spain, w: Colors Between ..., op. cit., s. 284-299; A. Russo, Postface: Uncatchable Colors, w: Colors Between ..., op. cit., s. 389-410.

19 W języku hiszpańskim istnieje bardziej popularne słowo używane przy opisywaniu stanu majątkowego - zarówno ruchomości, jak i nieruchomości, czyli ,dobra” (bienes). Spotyka się je w dokumentach powstałych w epoce kolonialnej, w inwentarzach i testamentach. Jednak w przypadku własności jezuitów używano terminu ,,doczesności” (temporalidades) dla określenia wszystkich własności i dóbr różnego typu, zarówno nieruchomości, jak i ruchomości zakonnych. E.J. A. Maeder, Los bienes de los jesuitas. Destino y administración de sus temporalidades en Río de la Plata 1767-1813, Resistencia 2001, s. 14; G. Jurado de Guerra, Visión general sobre la expulsion de los jesuitas decretada por el Rey Carlos III, w: Historia de la iglesia católica en el Ecuador, red. J. Salvador Lara, t. 3: La iglesia en Quito en el siglo XVIII, Quito 2003, s. 1557.

20 E. Kubiak, Reinterpretacje. Percepcja i recepcja dzieł architektury na przykładzie światyń jezuickich Ameryki Poludniowej okresu kolonialnego, Łódź 2015, s. 36-37.

21 Archivo General de la Nación (Lima, Peru), Fondo: Temporalidades (Inventarios) Caja 1, Legajo 13, Testimonio de los autos y diligencia que se siguieron para ocupar el Colegio de la Transfiguración de que los PP de la Compañía de Jesús, e inventarios que entones hicieron de los muebles y enseres del dicho Colegio altares y ornamentos de su Iglesia [1767], ff.68 (dalej: AGNP, 1/13).

22 Archivo Regional del Cusco (Cusco, Peru), Fondo Colegio de Ciencias, Legajo 5, Cuaderno 9, Inventario de la Capilla de Nuestra Señora de Loreto 1766-1767, ff.11 (dalej: ARC, 5/9).

${ }^{23} \mathrm{~W}$ tym wypadku istnieją dwie niemal identyczne wersje inwentarzy, które przechowywane są w dwóch różnych archiwach: Archivo Nacional de Chile (Santiago de Chile, Chile), Jesuitas del Perú, Legajo 347, Testimonio del Inventario de las Capillas de S.[a]n Bernardo y S.[a]n Francisco de Borja. Citas en la Ciudad del Cusco, f. 247 r.-325 v. (dalej: ANC, 347) i Archivo Regional del Cusco (Cusco, Peru), Fondo Colegio de Ciencias, Legajo 
wymienione budowle jezuickie powstały w drugiej połowie XVII w. ${ }^{24}$, a ich wyposażenie było wzbogacane do momentu wygnania członków Towarzystwa Jezusowego z terenów podległych koronie hiszpańskiej, co zostało zarządzone przez króla Karola III w 1767 r.

Inwentarze prezentują różny poziom szczegółowości, w zależności od terenów, na których powstawały, oraz osób, które przeprowadzały spisy. Inwentarze mają charakter „opisów gospodarskich", czyli bardziej zwracano uwagę na wartość materialną przedmiotów niż poziom artystyczny opisywanych obiektów. Relacje dotyczące obrazów ograniczają się do określenia ich wielkości i informacji na temat ram; często wymienione są także wezwania przedstawień, choć czasami ta ostatnia informacja jest pomijana zdawkowym „wiele wezwań/ de varias advocaciones" ${ }^{25}$. Za pośrednictwem inwentarzy nie można się dowiedzieć niczego na temat formy znajdujących się w świątyniach obrazów, ich poziomu wykonania czy użytych kolorów. Jednak, gdy opisy dotyczą innych obiektów wyposażenia kościoła i kaplic, pojawiają się także określenia barw. W niniejszym opracowaniu na marginesie rozważań pozostaną szaty liturgiczne, których opisy w inwentarzach zawsze są uporządkowane według kolorów, jednak nie stanowią one stałych elementów wystroju wnętrza, są elementem niejako podwójnie efemerycznym, ich zmienność podporządkowana jest świętom wpisanym w kalendarz liturgiczny ${ }^{26}$, a dodatkowo ich pojawienie się we wnętrzu sakralnym ograniczone jest do czasu obecności kapłana w kościele.

\section{Ze zlota i srebra}

Do dzisiaj kolorem dominującym w kościele jezuickim pod wezwaniem Przemienienia Pańskiego w Cusco jest złoto. Wiadomo, że świątynia jezuicka straciła integralność wystroju, a wiele z ołtarzy zostało umieszczonych w kościele później, co było wynikiem najpierw wygnania jezuitów i przekazania części wyposażenia innym kościołom, a potem zniszczenia kilku obiektów sakralnych w $\mathrm{Cusco}^{27}$ i przeniesienia elementów ich wystroju do świątyni jezuitów. Jednak bezsporne jest to, że wystrój prezbiterium kościoła nie uległ znaczącym zmianom (il. 3).

W inwentarzach, zarówno prezentowanego kościoła, jak i pozostałych kaplic jezuickich, w zakresie denominacji kolorów dominują określania „,dorado/dorada”, „de oro” i „,de plata”, czyli odnoszą się do kolorów złotego i srebrnego, a w wielu przypadkach także do materiału, z którego wykonano elementy wyposażenia. W sumie użyto takich określeń ponad 650 razy. Jest to zgodne z wrażeniem, jakie ma obserwator wchodzący do prezbiterium kościoła w Cusco. Imponujący ołtarz główny kościoła jest wykonany z drewna, bogato rzeźbiony i pokryty w całości złoceniami. Retabulum wypełnia całą ścianę zamknięcia prezbiterium, po bokach posiada niskie jednokondygnacyjne „skrzydła” ze zwieńczeniami, które ustawione

5, Cuaderno 15, Inventario de los Colegios de San Francisco de Borja y San Bernardo en la Ciudad del Cuzco 1767-1771, ff.14 (dalej: ARC 5/15).

${ }^{24}$ E. Kubiak, Reinterpretacje..., op. cit., s. 208-210; eadem, Architektura i wystrój kaplic w kolegiach jezuickich San Bernardo i San Francisco Borja w Cusco w świetle inwentarzy z 1768 r. [w druku].

${ }^{25}, 13$ Lienzos: los 8 de la vida de la Virgen, y los demas de varias advocaciones, todos con sus Chorcholas doradas", AGNP, 1/13, f. 67 r.

26 E.P. Victorio Cánovas, Piedad y suntuosidad: los ornamentos litúrgicos de tres colecciones limeñas, „Sztuka Ameryki Łacińskiej/ Arte de América Latina”, 2020, nr 10, s. 89.

27 Mowa tu o kasacie i rozebraniu kościoła i klasztoru augustianów, zmianie funkcji kaplicy szpitalnej świętego Andrzeja czy zniszczeniu kaplic kolegiów jezuickich. 

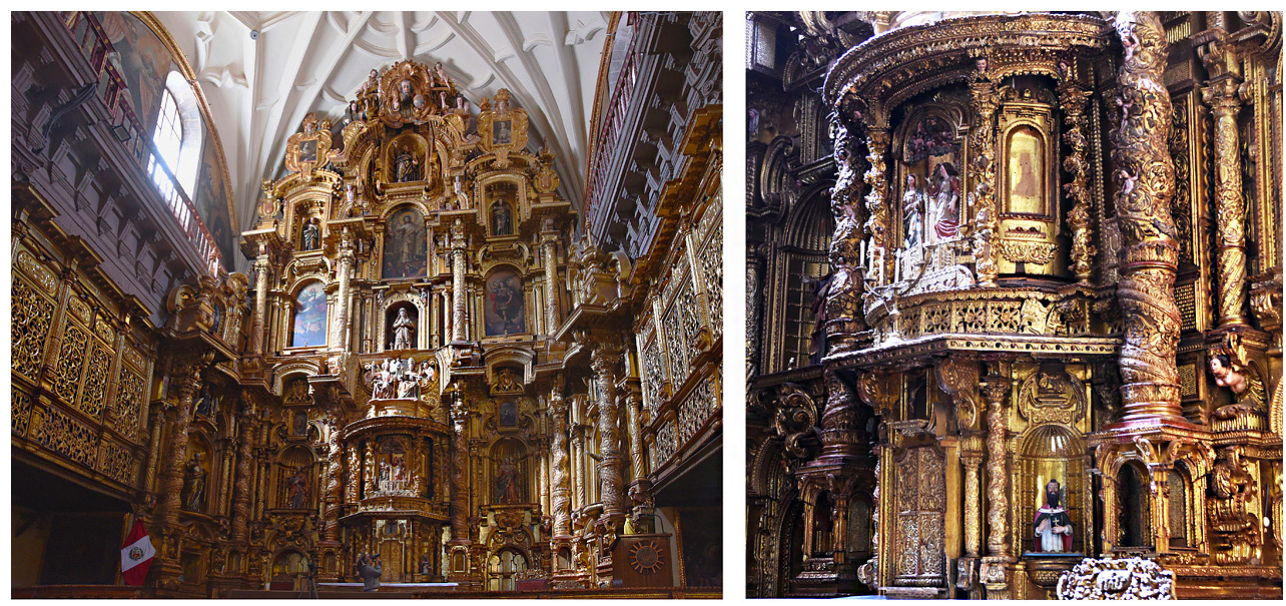

Il. 3. Ołtarz główny kościoła jezuitów w Cusco, widok całości i tabernakulum, II poł. XVII w. (fot. E. Kubiak, 2020)

są niemal prostopadle na tle ścian bocznych. Dalej po obu stronach struktura ołtarza łączy się z drewnianymi konstrukcjami zamkniętych balkonów, określanych w inwentarzu jako „trybuny” ${ }^{28}$, także wykonanych z drewna i złoconych. W inwentarzu zapisano, że jest to „retabulum duże, złocone o pięciu kondygnacjach”29. W kaplicach kolegialnych ołtarze główne także były złocone, w kolegium San Francisco de Borja „ołtarz złocony w znaczącej części” "30, a w San Bernardo „ołtarz złocony z trzema figurami” ${ }^{31}$.

Poza ołtarzami (nie tylko głównymi) złoceniami pokrywane były także inne elementy snycerki, przede wszystkim ramy obrazów, ale także zdobienia podłuczy arkad, pulpity pod księgi, antependia, podesty do umieszczania figur, ambony czy drewniane atrybuty świętych, jak w przypadku wizerunku Świętej Gertrudy z ołtarza bocznego kościoła Przemienienia Pańskiego: „która znajduje się pośrodku niszy odziana w strój z czarnego aksamitu z pastorałem ze złoconego drewna" ${ }^{32}$. Niekiedy złocenia odnoszą się także do wykończenia rzeźb wykonanych w stiuku jak, ,figura Świętego Michała z jego hełmem w stiuku, w złoconym stroju z tej samej materii" 33 . W wielu przypadkach określenie złoty czy złocony mówi o samym materiale, szczególnie w opisach naczyń liturgicznych i przedmiotów rzemiosła

\footnotetext{
28 „tribuna”, AGNP, 1/13, f. 10r.

29 „el Altar maior Un retablo grande Dorado De Cinco ordenes”. Ibidem, f. 28 v. W tym wypadku użyto określenia „W pięciu porządkach” w znaczeniu kondygnacji, co wynika z dalszego opisu ołtarza, choć w języku hiszpańskim zwykle używa się w takich przypadkach określenia „cuerpo”, także w inwentarzach.

30 „un Retablo dorado en lo principal”, ANC, 347, f.297 r.; ARC, 5/15, f. 3v.

31 „un Retablo dorado con tres bultos”, ANC, 347, f.253 v.; ARC, 5/15, f. 6v.

32 „la efigie de santa Gertrudis que esta en medio de un nicho con su vestido de terciopelo negro traido, su Baculo de Madera dorado", AGNP, 1/13, f. 25r.

33 „un San Miguel de bulto, con su gorrion de pasta y vestido dorado sobre la mesma especie”, ibidem, f.25v.
} 
artystycznego, takich jak: kielichy, ampułki, pateny, relikwiarze czy świeczniki. Wreszcie złoceniami zdobiono także tkaniny strojów, w które ubierano figury świętych ${ }^{34}$.

Podobne przedmioty opracowywano w srebrze (il. 4). Nie ma obiektów srebrzonych, ale tych wykonanych ze srebra było zdecydowanie więcej niż wykonanych ze złota. Są zatem dwa srebrne antependia (frontales), które w inwentarzach opisano dość szczegółowo. W kaplicy Virgen de Loreto zostało krótko scharakteryzowane antepedium znajdujące się w ołtarzu głównym z repusowanymi wizerunkami Świętych Ignacego Loyoli i Franciszka Ksawerego oraz Matki Boskiej Loretańskiej ${ }^{35}$. Zaś w kaplicy kolegium San Bernardo opisano inne srebrne antependium z pojedynczym wizerunkiem maryjnym ${ }^{36}$. Ze srebra wykonywano większość naczyń liturgicznych, a także proste świeczniki (blandones), kandelabry oraz świeczniki na świece dużych rozmiarów (hacheros) czy też pulpity pod księgi (atriles). Często także wykonywano przedmioty z drewna, a następnie pokrywano je srebrną blachą, jak na przykład dużych rozmiarów pulpit muzyczny (facistol) ${ }^{37}$ w kościele Przemienienia Pańskiego czy tablice z zestawieniem ewangelii w kaplicy Matki Boskiej Loretańskiej ${ }^{38}$.

Złoto i srebro było cenione zarówno w Europie, jak i świecie andyjskim funkcjonującym przed konkwistą hiszpańską. Określenia „oro” i ,plata” w odniesieniu do metali szlachetny pojawia się już w pierwszym słowniku języka hiszpańskiego autorstwa Antoniego de Nebrijy $^{39}$, a także potem od początku XVIII w. w każdym słowniku Królewskiej Akademii Hiszpańskiej (Real Academia Española). Złoto zostało określone jako „metal najcenniejszy ze wszystkich [...] lśniący, przepiękny”40, a srebro opisane jako „drogi metal w białym kolorze, który powstaje i tworzy się w kopalniach pod ziemią, i zaraz po złocie jest najszlachetniejszy ze wszystkich"41. W okresie nowożytnym rozwijały się także badania na temat metali szlachetnych, a w traktatach naukowych złoto i srebro zajmowało bardzo ważne miejsce, jak w publikacji Álvara Alonsa Barby El arte de los metales z $1641 \mathrm{r}^{42}$

W okresie prekolumbijskim znacznie złota i srebra także było ogromne. Przedmioty wykonywane z tych metali doceniano nie ze względu na cenny materiał, ale na wrażenia

\footnotetext{
34 Złocenia znajdowaly sie także na obrazach sztalugowych; J. Rodrígez Nóbrega, Nuevas visiones sobre antiguos esplendores: el dorado en la pintura barroca sudamericana, w: Visiones renovadas del barroco iberoamericano, red. F. Quiles García, Mª del Pilar López, Sevilla 2016, s. 74-97.

35 „Yten un Frontal De plata De hechura antigua obra llana con sus Sobre puestos De San Ygnacio, San Fransisco [Francisco] Xavier y Nuestra señora de Loreto", ARC, 5/9, f.1r.

36 „Yten un Frontal de plata con su Ymagen de Nuestra Señora dorado con vara y quarta de alto, y tres varas de largo", ANC, 347, f.255 r.; ARC, 5/15, f. 8r.

37 „Yten um Facistol con el Alma de Madera y forro de plata, la que segun regulacion tiene diez y seis Marcos”, AGNP, 1/13, f.43v.

38 „Yten una Tablilla De evangelio con su alma De madera y una vara De Guion con seis cañotos De plata”, ARC, $5 / 9$, f.5r.

39 A. de Nebrija, Vocabulario español-latino, Salamanca 1495.

40 „Metal el mas precioso de todos”, Diccionario de la lengua castellana, en que se explica el verdadero sentido de las voces, su naturaleza y calidad, con las phrases y modos de hablar, los proverbios y refrantes, y otras cosas conveninetes al. uso de la lengua, t. 5, Madrid 1737, s. 59.

41 „metal precioso de color blanco, que prodece y cria en sus minas de tierra, y despues del oro es el mas noble de todos", ibidem, s. 420.

42 Pierwsze wydanie traktatu miało miejsce w Madrycie w 1641 r., ja jednak korzystałam z później wydanej publikacji południowoamerykańskiej z początku XIX w.; A.A. Barba, El arte de los metales en que se enseña el verdadero beneficio de los de oro, y plata por azogue. El modo de fundirlos todos, y como se han de refinar, y apartar unos de otros, Lima 1817 [Madrid 1641].
} 

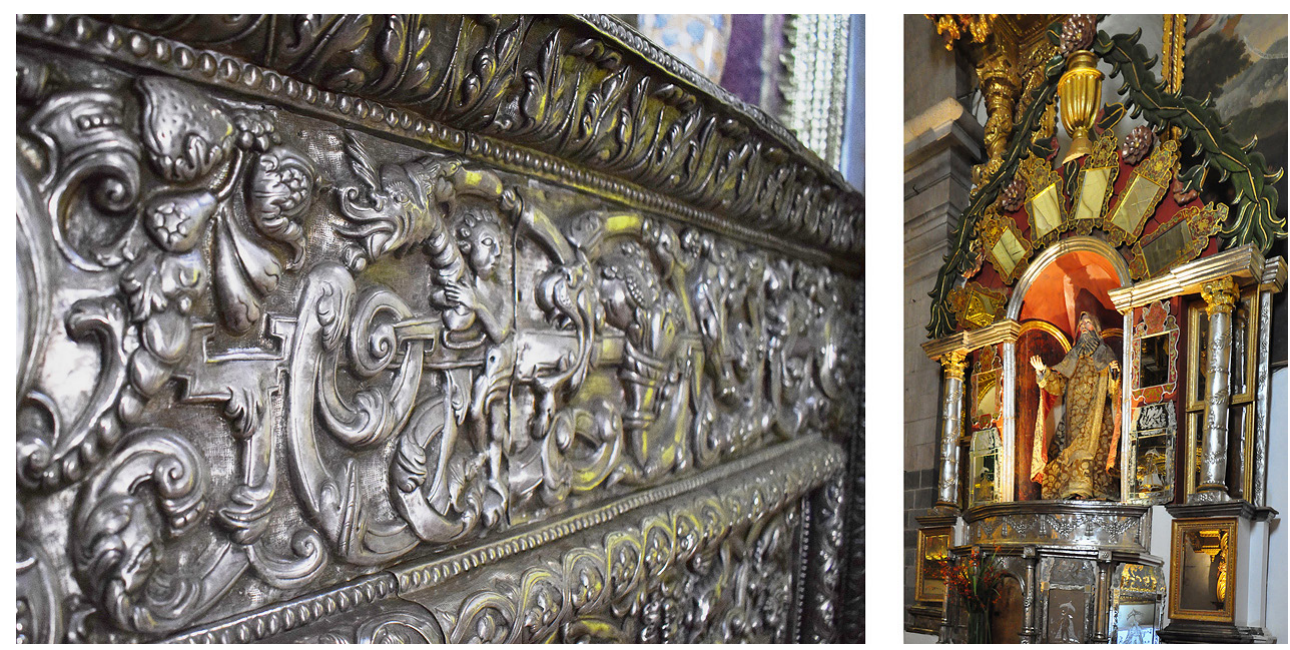

Il. 4. Antependium ołtarza głównego w kościele parafialnym pod wezwaniem Matki Boskiej Niepokalanie Poczętej w Checacupe, XVIII w.; Ołtarz boczny Świętego Antoniego w dawnej kaplicy uniwersyteckiej San Antonio Abad w Cusco, II poł. XVIII w. (fot. E. Kubiak, 2018)

wizualne, które wywoływały: blask i barwę ${ }^{43}$. W okresie inkaskim można odnotować migrację artystów i ich warsztatów złotniczych do Cuzco i okolic, gdzie pracowali dla władcy, jego rodziny i przedstawicieli szlachty inkaskiej ${ }^{44}$. Warsztaty złotnicze znajdowały się także w centrach ceremonialnych, gdzie wytwarzano obiekty o charakterze kultowym, a grupy rzemieślników i produkowane przedmioty podlegały kontroli państwa ${ }^{45}$.

W okresie kolonialnym Cusco było jednym z ważniejszych centrów złotnictwa w andyjskim regionie Wicekrólestwa Peru ${ }^{46}$. W 1572 r. wicekról Francisco de Toledo wydał rozporządzenie w sprawie złotników (Ordenazas de Plateros), które zakładało, że wszyscy indiańscy rzemieślnicy zajmujący się tą profesją zostaną skupieni w Cusco. W związku z tym w parafii Santiago powstała dzielnica, gdzie zamieszkali złotnicy z różnych stron wicekrólestwa, także z odległych regionów wybrzeża ${ }^{47}$.

\section{Varios colores}

We wnętrzach sakralnych poza kolorami złotym i srebrnym żaden inny nie cieszył się tak ogromną popularnością. Dość często można znaleźć określenie dotyczące wielobarwności, niektóre przedmioty były „kolorowane” (colorados) lub były w „,różnych kolorach” (de varios colores/ diferentes colores), a jeszcze inne „malowane” (pintado). Wielobarwność i blask

\footnotetext{
43 L.M. Vetter Parodi, Plateros y saberes andinos. El arte orfebre en los siglos XVI-XVII, Cusco 2016, s. 53.

44 L.E. Wuffarden, Los plateros: notas sobre la evolución de un oficio artístico (1532-1900), w: Plata de los Andes, red. R. Kusunoski, L.E. Wuffarden, Lima 2018, s. 24.

45 L.M. Vetter Parodi, op. cit., s. 87.

46 L.E. Wuffarden, op. cit., s. 35.

47 L.M. Vetter Parodi, op. cit., s. 87-88. Innym miejscem ważnym ze względu na wydobycie, ale i obróbkę srebra było Potosi.
} 
zapewniały także dość powszechnie obecne lustra (espejos), które wykorzystywano jako elementy dekoracji ołtarzy (przede wszystkim tabernakulów ${ }^{48}$ ), ram obrazów oraz łuków i podłuczy.

W opisach pojawiały się oczywiście także denominacje konkretnych barw, jest zatem biały (blanco) i czarny (negro), a także niebieski (azul), zielony (verde) i żółty (amarillo). Brak natomiast w inwentarzach najpopularniejszego dziś określenia koloru czerwonego (rojo ${ }^{49}$, ale pojawia się za to barwa różowa (rosa), fioletowa (morada) i karmazynowa (carmesí). Kolor karmazynowy wytwarzano w Peru z wykorzystaniem naturalnego barwnika określanego jako kwas karminowy, pozyskiwanego z owadów nazywanych czerwcami kaktusowymi lub po hiszpańsku cochinillas. Stały się one także towarem eksportowym. José de Acosta w swojej historii Ameryki z 1590 r. pisał, że owady zbiera się z krzewów kaktusowych opuncji, „suszy się je i takie wysuszone przewozi do Hiszpanii, i tam są cennym towarem, a arroba $^{50}$ koszenili lub inaczej karminy warta jest wiele dukatów"51, ponieważ dzięki nim otrzymuje się barwnik w kolorze „,delikatnego szkarłatu”, ${ }^{2}$.

Wśród szlachetnych kamieni o zdecydowanych barwach odnaleźć można przede wszystkim zielone szmaragdy (esmeraldas), które zdobiły między innymi tabernakulum ołtarza głównego w kaplicy San Bernardo ${ }^{53}$, ale także do dziś znajdują się w zakończeniach gwoździ Ukrzyżowanego Chrystusa (Señor de Burgos) z ołtarza w transepcie kościoła jezuitów w Cusco (il. 5). W inwentarzu świątyni wymieniony jest zresztą inny krucyfiks z figurą Chrystusa, który w całości ozdobiony był szmaragdami ${ }^{54}$. Ogromna większość szlachetnych kamieni, w tym także szmaragdów, dekorowała naczynia liturgiczne, takie jak monstrancje ${ }^{55}$, kielich $^{56}$, tacę i ampułki ${ }^{57}$, można je odnaleźć również we wspomnianym już tabernakulum i jako elementy składające się na biżuterię, którą zdobiono wizerunki rzeźbiarskie. Figury Matki Boskiej i świętych dekorowano koronami, pierścieniami, naszyjnikami czy też kolczykami. W języku hiszpańskim określa się te dodatkowe ozdoby jako indumentaria postiza ${ }^{58}$.

48 ,el interior del Sagrario una peaña de Espejos pequeños, y por los lados guarnecidos de otros medianos, y por cimientos de esta pieza trece espejos", AGNP, 1/13, f.26r.

49 „Rojo” jako określenie koloru nie istnieje jeszcze w słowniku Antoniego de Nebrijy, ale w osiemnastowiecznych słownikach wyraz pojawia się już w znaczeniu koloru; Diccionario de la lengua castellana ..., op. cit., t. 2, 1729, s. 183.

50 Arroba jest jednostką wagi, która wynosi 11 kg i 502 gr. Diccionario historico de la lengua española, t. 1, Madrid 1933, s. 795.

51 „,déjanlos secar, y así secos los traen a España, que es una rica y gruesa mercadería; vale la arroba de esta cochinillla o grana, muchos ducados". J. de Acosta, Historia natural y moral de las Indias, red. E. O'Gorman, México 2006 [1590], s. 205.

52 „la grana fina”, ibidem.

53 „Yten en dicho Sagrario una Joya de orro con siete esmeraldas y seis piedras moradas finas”, ANC, 347, f.260v.; ARC, 5/15, f. 13r.

54 „Un Santo Cristo, y se adbierte qe [que] las esmeraldas son de todo el Cuerpo”, AGNP, 1/13, f.28v.

55 „una Custtodia De Plata Dorada con su pie De lo mismo y los raios y Cerco con algunas esmeraldas y muchas piedras Coloradas”, ibidem, f.28v.; ,Yten una custodia de plata dorada con sobre puestos de lo mesmo, esmeraldas", ibidem. F.41v.

56 „Yten un Caliz de Oro, hechura filigrana, con ciento treinta y tres esmeraldas, Ciento once perlas menudas y doscientas ochenta y dos dichas mas pequeñas", ibidem, f.41r.

57 „Yten una Salvillita con veinte esmeraldas y catorce perlas medianas, y un par de Vinageras hechura de filigrana con treinta esmeraldas y treinta perlas, entre grandes y pequeñas", ibidem.

58 Pisze o tym Olga Acosta: O.I. Acosta Luna, Milagrosas imágenes marianas en el Nuevo Reino de Granada, Madrid-Frankfurt am Main, 2011, s. 381-386. 


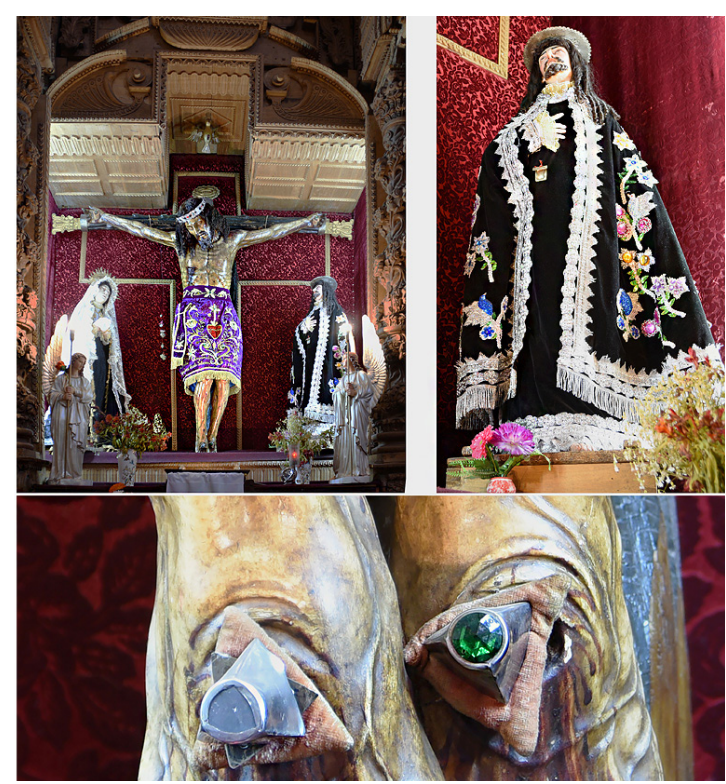

I1. 5. Señor de Burgos z Matką Boską i Świętym Janem, nisza w ołtarzu w transepcie kościoła jezuitów, Cusco, XVIII w. (fot. E. Kubiak, 2020)

\section{Podsumowanie}

Na zakończenie tego krótkiego przeglądu wystroju jezuickich wnętrz sakralnych w Cusco warto wymienić trzy grupy obiektów, które były bardzo ważnymi elementami wyposażenia, a jednocześnie zwracały uwagę swoją bogatą kolorystyką: złocone tabernakula i wielobarwne antependia oraz stroje rzeźbionych wizerunków świętych $^{59}$. W moim przekonaniu najbardziej wystawne, barwne i pełne blasku były tabernakula. Można to wiązać ze szczególnym rozwojem kultu eucharystycznego pojmowanego jako jeden z elementów programu ewangelizacyjnego. W tym kontekście istotne było uwzględnienie święta Bożego Ciała w Ordynacjach wicekróla Toledo ${ }^{60}$ dla miasta Cuzco (Ordenanzas del virrey Toledo para la ciudad del Cuzco) z 1572 r. ${ }^{61}$ Zapisano tam, że Corpus Christi jest najważniejszym świętem

w roku liturgicznym i ma być celebrowany wystawną procesją. Pochód miał rozpoczynać corregidor $^{62}$ niosący sztandar z Najświętszym Sakramentem, a za nim podążali podtrzymujący baldachim burmistrz (alcalde) i radni, następnie pozostali urzędnicy, sędzia Indian, główny prokurator i pisarz miejski ${ }^{63}$. Interesujące jest również to, że w Cusco w czasach rządów biskupa Manuela de Mollinedo y Angulo (1673-1699) sztuka złotnicza stała się jednym z punktów szeroko zakrojonej polityki episkopalnej mającej na celu intensyfikację kultu Najświętszego Sakramentu. Związana z tym była zarówno produkcja naczyń liturgicznych,

\footnotetext{
59 Olga Acosta podkreśla zmienność strojów figur ołtarzowych i procesyjnych, która podlegała kalendarzowi roku liturgicznego, w związku z tym, podobnie jak szaty liturgiczne miała niejako charakter przejściowy, efemeryczny; ibidem, s. 376-379.

60 Francisco de Toledo był wicekrólem Peru w latach 1569-1581. Za jego rządów przeprowadzono reformy zarówno ekonomiczne, jak i społeczne, które można potraktować jako kluczowy moment w procesie kształtowania się systemu kolonialnego; J. Pietraszczyk-Sękowska, Tradycje oporu w Andach. Mobilizacje indiańskochłopskie w Peru od XVI do XX wieku, Łódź 2015, s. 53; V. Roel Pineda, Historia social y económica de la colonia, Lima 1999, s. 97-98.

${ }^{61}$ F. de Toledo, Libro de visita general del virrey don Francisco de Toledo, 1570-1575, red. Carlos A. Romero, „Revista Histórica”, 7/1924, nr 2, s. 113-216.

${ }^{62}$ Corregidor jest funkcją urzędniczą, charakterystyczną dla Hiszpanii i jej kolonii, która w Peru wprowadzona została w 1560 r. Człowiek nominowany na to stanowisko sprawował w imieniu króla władzę administracyjną i sądowniczą w mieście lub całym regionie, a w realiach kolonialnych miał też za zadanie czuwać nad złagodzeniem wyzysku wobec ludności tubylczej; J. Pietraszczyk-Sękowska, op. cit., s. 45; V. Roel Pineda, op. cit., s. 89-94.

${ }^{63}$ F. de Toledo, Libro de visita general del virrey don Francisco de Toledo, 1570-1575, red. C.A. Romero, „Revista Histórica", 7/1924, nr 2, s. 187-190.
} 
jak i dekoracja tabernakulów i samych ołtarzy ${ }^{64}$. Według kronikarza Diega de Esquivela y Navii za czasów biskupa Mollinedo y Angulo nastąpiło wzmocnienie kultu Najświętszego Sakramentu, a wśród przedmiotów ufundowanych przez biskupa w kościołach kuzkeńskich autor wymienia: „osiemdziesiąt dwie monstrancje ze srebra, dwadzieścia antependiów ze srebra, dwadzieścia jeden lamp, nie licząc kielichów, świeczników, trybularzy, ampułek i innych cennych przedmiotów. Ofiarował [też] katedrze tabernakulum wykonane ze srebra"65.

Nic zatem dziwnego, że opisy w inwentarzach kościoła i kaplic jezuickich odzwierciedlają tę szczególną dbałość o naczynia liturgiczne i tabernakula, ich dekoracje, wystawność i blask, który był odbiciem sacrum. Jest to zresztą tendencja ogólna wystroju wnętrz świątyń kuzkeńskich. Nie można zatem, w moim przekonaniu, szukać powiązań bogactwa opisywanych wnętrz z jednym ze znaczeń „stylu jezuickiego”, który rozumiano między innymi także jako „,bogactwo form i dekoracji”66.

\section{Bibliografia}

Acosta J. de., Historia natural y moral de las Indias, red. E. O’Gorman, México 2006 [1590].

Acosta Luna O. I., Milagrosas imágenes marianas en el Nuevo Reino de Granada, Madrid-Frankfurt am Main 2011.

AGNP, 1/13 - Archivo General de la Nación (Lima, Peru), Fondo: Temporalidades (Inventarios) Caja 1 Legajo 13 Testimonio de los autos y diligencia que se siguieron para ocupar el Colegio de la Transfiguración de que los PP de la Compañia de Jesús, e inventarios que entones hicieron de los muebles y enseres del dicho Colegio altares y ornamentos de su Iglesia [1767], ff. 68.

ANC, 347 - Archivo Navional de Chile (Santiago de Chile, Chile), Jesuitas del Perú, Legajo 347, Testimonio del Inventario de las Capillas de S.[a $]^{\mathrm{n}}$ Bernardo y S.[a $]^{\mathrm{n}}$ Francisco de Borja. Citas en la Ciudad del Cusco, f. 247 r.-325 v.

ARC, 5/15 - Archivo Regional del Cusco (Cusco, Peru), Fondo Colegio de Ciencias, Legajo 5, Cuaderno 15, Inventario de los Colegios de San Francisco de Borja y San Bernardo en la Ciudad del Cuzco 1767-1771, ff.14.

ARC, 5/9 - Archivo Regional del Cusco (Cusco, Peru), Fondo Colegio de Ciencias, Legajo 5, Cuaderno 9, Inventario de la Capilla de Nuestra Señora de Loreto 1766-1767, ff.11.

Barba A. A., El arte de los metales en que se enseña el verdadero beneficio de los de oro, y plata por azogue. El modo de fundirlos todos, y como se han de refinar, y apartar unos de otros, Lima 1817 [Madrid 1641].

Bargellini C., The Colors of the Virgin of Guadalupe, w: Colors Between Two Worlds: The Florentine Codex of Bernardino de Sahagún, red. G. Wolf, J. Connors, L. Waldman, Florence 2011, s. 3-25.

Blum D. E., Textiles in Colonial Latin America, w: The Arts in Latin America, red. J.J. Rishel, S. Stratton-Pruir, Mexico City, New Haven, London, 2006, s. 146-154.

Bruquetas Galán R., Local and Importes colors: The Spanish Maritme Trade and the Pigment Supply in New Spain, w: Colors Between Two Worlds: The Florentine Codex of Bernardino de Sahagún, red. G. Wolf, J. Connors, L. Waldman, Florence 2011, s. 284-299.

Cerceda V., Semiología de los textiles andinos: las talegas de Isluga, „Chungara. Revista de Antropología Chilena", 42/2010, nr 1, s. 181-198.

${ }^{64}$ L.E. Wuffarden, op. cit., s.35.

65 D. Esquivel y Navia, Noticias cronológicas de la gran ciudad del Cuzco, wyd. F. Denegri Luna, t. 2, Lima 1980, s. 175 .

${ }^{66}$ E. Kubiak, Reinterpretacje..., op. cit., s. 100-102. 
Cereceda V., O pewnych aspektach estetyki ajmarsko-andyjskiej: od pojęcia piękna do tinku, tłum. N. Pluta, w: Estetyka Indian Ameryki Poludniowej. Antologia, red. K. Zajda, Kraków 2007, s. 19-37.

Diccionario de la lengua castellana, en que se explica el verdadero sentido de las voces, su naturaleza y calidad, con las phrases y modos de hablar, los proverbios y refrantes, y otras cosas conveninetes al. uso de la lengua, t. 2, Madrid 1729.

Diccionario de la lengua castellana, en que se explica el verdadero sentido de las voces, su naturaleza y calidad, con las phrases y modos de hablar, los proverbios y refrantes, y otras cosas conveninetes al. uso de la lengua, t. 5, Madrid 1737.

Diccionario historico de la lengua española, t. 1, Madrid 1933.

Esquivel y Navia D., Noticias cronológicas de la gran ciudad del Cuzco, wyd. F. Denegri Luna, t. 2, Lima 1980.

Gisbert T., Arze S., Cajías M., Arte Textil y Mundo Andino, La Paz (Bolivia) 2015 [1988].

Guibovich Pérez P., Wuffarden L. E., Sociedad y gobierno episcopal: las visitas del obispo Mollinedo y Angulo (Cuzco 1674-1694), Lima 2008.

Jurado de Guerra G., Visión general sobre la expulsión de los jesuitas decretada por el Rey Carlos III, w: Historia de la iglesia católica en el Ecuador, red. J. Salvador de Lara, t. 3: La iglesia en Quito en el siglo XVIII, Quito 2003, s. 1551-1558.

Kubiak E., Architektura i wystrój kaplic w kolegiach jezuickich San Bernardo i San Francisco de Borja w Cusco w świetle inwentarzy z 1768 r. [w druku].

Kubiak E., Reinterpretacje. Percepcja i recepcja dziet architektury na przykładzie światyń jezuickich Ameryki Poludniowej okresu kolonialnego, Łódź 2015.

Macera P., La pintura mular andina. Siglos XVI-XIX, Lima 1993.

Maeder E.J.A., Los bienes de los jesuitas. Destino y administración de sus temporalidades en Río de la Plata 1767-1813, Resistencia 2001.

Nebrija A. de, Vocabulario español-latino, Salamanca 1495.

Phipps E., Color in the Andes: Inca Garments and 17th-Century Colonial Documents, „Dyes in History and Archaeology", 2003, nr 19, s. 51-60.

Phipps E., Cumbi to Tapestry: Collection, Innovation, and Transformation of the Colonial Andean Tapestry Tradition, w: The Colonial Andes. Tapestries and Silverwork, 1530-1830, red. E. Phipps, J. Hecht, C.E. Martín, New York-New Haven-London 2004, s. 73-99.

Phipps E., Textile Colors and Colorants in the Andes, w: Colors Between Two Worlds: The Florentine Codex of Bernardino de Sahagún, red. G. Wolf, J. Connors, L. Waldman, Florence 2011, s. 257-280.

Phipps E., Turner N., Trentelman K., Colors, Textiles, and Artistic Production in Murúa's Historia General del Piru, w: The Getty Murúa. Essays on the Making of Martín de Murúa's Historia General del Piru, J. Paul Getty Museum Ms. Ludwig XIII 16, red. T.B. F. Cummins, B. Anderson, Los Angeles 2008, s. 125-145.

Pietraszczyk-Sękowska J., Tradycje oporu w Andach. Mobilizacje indiańskochłopskie w Peru od XVI do XX wieku, Łódź 2015.

Rodrígez Nóbrega J., Nuevas visiones sobre antiguos esplendores: el dorado en la pintura barroca sudamericana, w: Visiones renovadas del barroco iberoamericano, red. F. Quiles García, $\mathrm{M}^{\mathrm{a}} \mathrm{del}$ Pilar López, Sevilla 2016, s. 74-97.

Roel Pineda V., Historia social y económica de la colonia, Lima 1999.

Russo A., Postface: Uncatchable Colors, w: Colors Between Two Worlds: The Florentine Codex of Bernardino de Sahagún, red. G. Wolf, J. Connors, L. Waldman, Florence 2011, s. 389-410.

Seldes A. M., Burucúa J. E., Maier M. S., Abad G., Jáuregui A., Siracusano G., Blue Pigments In South American Painting (1610-1780), „Journal of the American Institute for Conservation”, 38/1999, nr 1, s. 100-123. 
Seldes A. M., Burucúa J. E., Siracusano G., Maier M. S., Abad G. E., Green, Red and Yellow Pigments In South American Painting (1610-1780), „Journal of the American Institute for Conservation”, 41/2002, nr 3, s. 225-242.

Siracusano G., Coloreando el ánimo de los fieles: saberes y poderes del color en el pensamiento jesuita, siglos XVI-XVII, w: Los jesuitas y la modernidad en Iberoamérica (1549-1773), red. M. Marzal, L. Bacigalupo, t. 2, Lima 2007, s. 105-116.

Siracusano G., Colors and Cultures in the Andes, w: Colors Between Two Worlds: The Florentine Codex of Bernardino de Sahagún, red. G. Wolf, J. Connors, L. Waldman, Florence 2011, s. 367-377.

Siracusano G., El poder de los colores. De lo material a lo simbólicoen las practicas culturales andinas. Siglos XVI-XVIII, Buenos Aires 2005.

Toledo F. de, Libro de visita general del virrey don Francisco de Toledo, 1570-1575, red. C.A. Romero, „Revista Histórica”, 7/1924, nr 2, s. 113-216.

Vetter Parodi L. M., Plateros y saberes andinos. El arte orfebre en los siglos XVI-XVII, Cusco 2016.

Victorio Cánovas E. P., Piedad y suntuosidad: los ornamentos litúrgicos de tres colecciones limeñas, „Sztuka Ameryki Łacińskiej/ Arte de América Latina”, 2020, nr 10, s.75-100.

Viñuales G. M., Gutiérrez R., Historia de los pueblos de indios de Cusco y Apurímac, Lima 2014.

Wuffarden L. E., Los plateros: notas sobre la evolución de un oficio artístico (1532-1900), w: Plata de los Andes, red. R. Kusunoski, L.E. Wuffarden, Lima 2018, s. 17-56. 